\title{
Nanoemulsions for health, food, and cosmetics: a review
}

\author{
Tolulope Joshua Ashaolu' ${ }^{1}$
}

Received: 24 December 2020 / Accepted: 3 March 2021 / Published online: 15 March 2021

(c) The Author(s), under exclusive licence to Springer Nature Switzerland AG 2021

\begin{abstract}
Nanoemulsions are gaining importance in healthcare and cosmetics sectors as a result of the unique properties of nanosized droplets, such as high surface area. Here we review nanotechnology and nanoemulsions with focus on emulsifiers and nanoemulsifiers, and applications for drugs and vaccines delivery, cancer therapy, inflammation treatment, cosmetics, perfumes, polymers, and food. We discuss nanoemulsion safety and properties, e.g., stability, emulsification, solubility, molecular number and arrangements, ionic strength, $\mathrm{pH}$ and temperature.
\end{abstract}

Keywords Nanotechnology $\cdot$ Nanoparticles $\cdot$ Nanoemulsions $\cdot$ Emulsifiers $\cdot$ Applications

\section{Introduction}

Nanotechnology is developing rapidly in many sectors, especially cosmetics, pharmaceutics, agriculture and food industries (Chowdhury et al. 2017). Most of these interests are geared toward the development of lipophilic substances like fatty acids, flavors, colors, and drugs (Azmi et al. 2019). The need for using nanotechnology/nanoparticles in emulsion fabrication is crucial because emulsions have been produced from numerous ingredients and additives for so many years, creating markets and profitability. Carbohydrates, fats, proteins and other active components such as antioxidants, colorings, acidulants, flavorings, preservatives, benzoic acid, coenzyme-Q10, vitamins A and E, isoflavones, beta-carotene, citric acid, ascorbic acid, lutein, omega-3 fatty acids, minerals, among other bioactive compounds have contributed to improved taste, appearance, texture, fortification and stability, and as such innovatively inspired wide applications of nanoemulsions to foods for enhanced uptake, absorbability and bioavailability (Kumar and Sarkar 2018; Mcclements and Jafari 2018; Dasgupta et al. 2019a; Walia et al. 2019; Saini et al. 2020).

Research into nanoemulsions is extensive. These emulsions are disequilibrated systems of water-in-oil (W/O) or

Tolulope Joshua Ashaolu

tolulopejoshuaashaolu@duytan.edu.vn

1 Institute of Research and Development, Faculty of Environmental and Chemical Engineering, Duy Tan University, Da Nang 550000, Vietnam oil-in-water (O/W) emulsions (Fig. 1) within nanometerrange particle sizes and droplet diameters of $50-1000 \mathrm{~nm}$ (Yukuyama et al. 2016); otherwise, nanoemulsions are referred to as dispersed systems with $\leq 100 \mathrm{~nm}$ droplets (Azmi et al. 2019). Nanoemulsions are immiscible liquids consisting of oil and water forming a single phase by an emulsifier such as the surfactants and co-surfactants. The combination of these constituents confers high thermodynamics, stability and other physicochemical properties on the emulsion. Thus, the versatility of nanoemulsions becomes greater than that of conventional emulsions, including microemulsions and macroemulsions.

The Federal Drug Administration (FDA) has utilized molecularity and functions of some emulsifiers as the basis of approval for their use in pharmaceutical and food industries (McClements et al. 2017). Stability, emulsification and solubility of emulsions are inspired by their surface-active nature dovetailed with molecular number and arrangements, ionic strength, $\mathrm{pH}$ and temperature of the mixture (McClements et al. 2017). Since the preparations of nanoemulsions and their emulsifiers are crucial and paramount to the interests of key industries, the aim of the present review is to evaluate the concept of nanotechnology, the formation and the applications of nanoemulsions in the healthcare and cosmetics industries, as well as their potentials in foods and other sectors in this present century. Further considerations were also put forward. To conduct the review, web of science (WoS), google and springer search engines were used, using the words and phrases "nano", "nanosize", "nanotechnology", "emulsion”, "nanoemulsion”, "applications of 
Fig. 1 Oil-in-water and waterin-oil emulsions. Nanoemulsions are disequilibrated systems of water-in-oil (W/O) or oil-in-water $(\mathrm{O} / \mathrm{W})$ emulsions. They are immiscible liquids consisting of oil and water forming a single phase by an emulsifier such as the surfactants and co-surfactants, the combination of which confers high thermodynamics, stability and other physicochemical properties on the emulsion
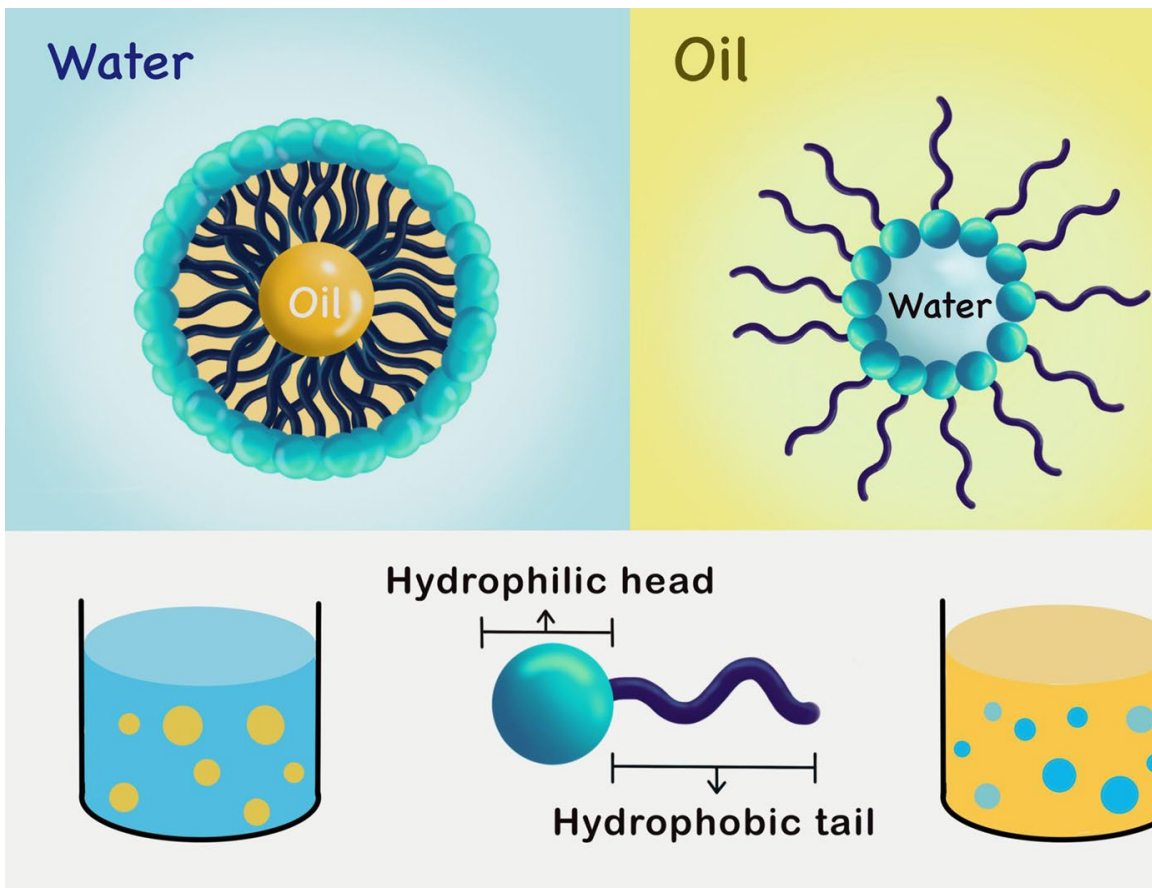

Hydrophilic head

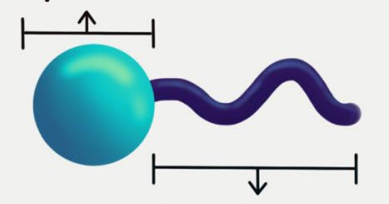

Hydrophobic tail

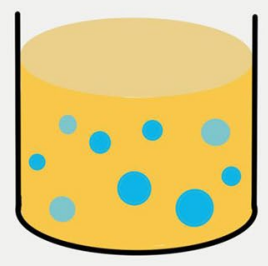

nanoemulsions" and "applications of emulsions", filtering the year range to 2000-2020.

\section{Nanotechnology and nanoemulsions}

Nanotechnology is a global concept that entails the manipulation of particles within the range of 10-1000 nm using scientific, innovative and well-characterized techniques, for improved productivity and applications in agriculture, healthcare, cosmetics, defense, energy and food sectors (Kaul et al. 2018; Feng et al. 2018; Aziz et al. 2019). The world's nanotechnology industry could worth 80 billion US dollars and could be reaching 17\% growth rate by 2024 . Therefore, the potential benefits and profits are huge in this emerging market (Research and Market 2018). Application of the technology to the food industry has always been towards emulsions, encapsulation and packaging technologies, of which nanoemulsions are of utmost economic importance (Dasgupta et al. 2019b).

Nanoemulsions are formed when an emulsifier is involved in the mixture of two immiscible liquids to form stable but kinetic dispersions with droplet sizes and diameters of $\leq 100 \mathrm{~nm}$ and $20-200 \mathrm{~nm}$, respectively. The kinetic stability is achieved when nanoparticles Brownian motion surpasses the emulsions' gravitational forces, which then stop the particles from aggregating (Wani et al. 2018). Being very minuscule in size, nanoemulsions offer great functional potentials such as enhanced stability, surface area, optical transparency, rheology and other functions associated with innovative technologies and fortification of many aqueous-based food and beverage products (Dasgupta et al. 2019b). Regarding nanoemulsions production, common methods used include high-pressure homogenization, phaseinversion temperature, ultrasonication, high-shear mixing, solvent displacement, emulsion inversion point, bubble bursting and spontaneous emulsification-all falling under the categories of low- and high-energy techniques (Mohammadi et al. 2016; O'Sullivan et al. 2018; Azmi et al. 2019; Dasgupta et al. 2019a, b).

Increasing rate of consumption of processed foods and beverages has led to increased use of food additives and processing aids such as emulsifiers, which are meant to enhance the texture, flavor, stability and shelf-life of foods (RocaSaavedra et al. 2018; Vo et al. 2019). The hydrophilic and hydrophobic molecular groups in emulsifiers contribute to immiscibility of the formulated liquids, which then lead to much enhanced homogeneity and stability in the final products as found in butter, mayonnaise, dressings, chocolates, ketchups and yogurts (Shah et al. 2017; Vo et al. 2019). Emulsifiers have been estimated to constitute more than $70 \%$ of the world's approved food ingredients (Shah et al. 2017), necessitating the importance and use of nanosized emulsifiers in this century.

\section{Emulsifiers and nanoemulsifiers for nanoemulsions}

Emulsifiers are surface-active molecules widely applied in the breakage of droplets into tiny and very small droplets. Emulsifiers concentration must reach the right amounts 
so as to overcome the interfacial forces, and to ensure that the coating rate is rapid (Artiga-Artigas et al., 2018). This phenomenon prevents the particles from aggregating whilst enabling longer storage time and better stability. Fabricating nanoemulsions implies that the emulsifiers are well absorbed at the oil-water interface and subsequently reduce the interfacial tension in order to loosen up the particles and easily disrupt the droplets. The emulsifiers then protectively coat the oil droplets to prevent aggregation and coagulation (Dasgupta et al. 2019a).

The mixture of oil and water in the process of emulsion formulation creates two immiscible phases based on the segregation caused by coalescing globules in dispersion. The use of emulsifiers or nanoemulsifiers from the generally regarded as safe (GRAS) agents and components, such as peptides, proteins, phospholipids, micro-molecular surfactants, and polysaccharides, for the production of emulsion systems in the appropriate ratios would contribute to their efficiency and stability. Table 1 illustrates some emulsifierstabilized nanoemulsions. This stability results from circumnavigation of processes like Oswald ripening, especially when the surfactants/emulsifiers are mixed with oil and other components in the right ratio (Gordon et al. 2003).

Over time, the formulated emulsions exhibit droplet coalescence characterized with various behavioral patterns such as heterogeneous or homogeneous growths, in which droplet sizes decrease and create early phase separation, or increase with time, respectively. Indeed, microparticulated emulsions will exhibit a higher degree of aggregation than nanoparticulated emulsions because of the irreversible droplets coalescence taking place with the former's bigger particle size (An et al. 2014). Moreover, the properties of emulsifier used, such as functional, sensory and physicochemical characteristics, can positively or negatively affect the rheology of the nanoemulsion droplets.

The hydrophile-lipophile balance (HLB) system (hydrophilic range $>10$, lipophilic range $=1-10$ ) should be considered when determining the right nano(emulsifiers) for nanoemulsions fabrication because the HLB system has been in use for more than half of the last century to prove optimum conditions of surfactants required for emulsions fabrication with desired characteristics (Macedo et al. 2006; Azmi et al. 2019).

Several studies on colloidal and nanoemulsion systems used emulsifiers due to their better interfacial diffusive properties compared to larger biopolymers, such as proteins and polysaccharides, but their metabolism and safety are of concern in the food industry (Adjonu et al. 2014). For protein and peptide-based emulsifiers, both plant and dairy sources have been widely investigated and applied in foods because they form a protectively strong film in the formed emulsions. They later become employed in nanoemulsions (Table 1d), with the most important of them being whey proteins. These proteins comprise $20 \%$ whey and $80 \%$ caseins with very high nutritional contents based on their essential amino acids composition. The whey proteins are basically $\alpha$-lactalbumin, $\beta$-lactoglobulin, bovine serum albumin, lactoferrins, and immunoglobulins, and possess amphiphilic properties that make them crucial emulsifiers in foods (Foegeding et al. 2002; Adjonu et al. 2014; Zhao and Ashaolu 2020). Under optimal control, hydrolyzation of the proteins will yield shorter peptides with fewer secondary and tertiary structures, to expose the hidden hydrophobic core (Christiansen et al. 2004; Ashaolu 2020a, b). These outcomes increase their diffusion rate and interfacial capacity when compared to their native parent proteins. Both hydrophilic and hydrophobic mixed groups generated further increase their absorption tendencies to the oil droplets surfaces, which ensure much better stability (van der Ven et al. 2001).

In brief, the advantages of nanoemulsifiers/nanoemulsions above emulsifiers include: they are small-sized droplets that have larger surface area for enhanced absorption, with much less energy requirement (Gurpreet and Singh 2018); they play active role in solubilization of lipophilic drugs and suppression of off-flavors of the drugs (Yu et al. 2012); they are considered non-toxic and non-irritant in nature (Jaiswal et al. 2015); they stabilize chemically unstable compounds by protecting them from oxidative and light degradation (Kim et al. 2001); they can substitute liposomes with vessicles (Bouchemal et al. 2004) and improve the bioavailability of a drug (Lovelyn and Attama 2011; Yu et al. 2012), while several types of nanoemulsions can be formed in the likes of creams, liquids, and sprays. On the flip side, in order to stabilize the nanodroplets, higher concentration of surfactant and cosurfactant may be required by nanoemulsifiers (Lovelyn and Attama 2011); solubilization of high-melting substances could be limited (Azmi et al. 2019); environmental parameters such as temperature and $\mathrm{pH}$ could affect the stability of nanoemulsifiers (Mishra et al. 2014); and the surfactants used pharmaceutical applications must be non-toxic (Mishra et al. 2014).

Moreover, the use of nanoemulsifiers is currently limited. Adjonu et al. (2014) quite well noted certain potentials of whey protein hydrolysates as emulsifying agents in nanoemulsions. Other than protein- or peptide-based nanoemulsifiers, other groups of molecules are described in Table 1. The continuous studies on nanoemulsions and its use in food applications require a whole lot of further in-depth analyses and critical evaluations, especially for their safety validation. 
Table 1 Emulsifiers in nanoemulsion systems

\begin{tabular}{|c|c|c|c|c|c|c|}
\hline Type of emulsifier & $\begin{array}{l}\text { Homogenization } \\
\text { technique }\end{array}$ & $\begin{array}{l}\text { Percentage of oil } \\
\text { used }\end{array}$ & $\begin{array}{l}\text { Percentage } \\
\text { of emulsifier } \\
\text { used }\end{array}$ & Oil phase used & $\begin{array}{l}\text { Droplet size diam- } \\
\text { eter }(\mathrm{nm})\end{array}$ & Citation \\
\hline \multicolumn{7}{|l|}{ a. Non-ionic } \\
\hline \multirow[t]{8}{*}{$\begin{array}{l}\text { Polyoxyethylene } \\
\text { sorbitan mon- } \\
\text { olaurate }\end{array}$} & $\begin{array}{l}\text { Microfluidization/ } \\
\text { high-pressure } \\
\text { valve homog- } \\
\text { enizer }\end{array}$ & $0.03,1$ & 1,10 & Sunflower oil & $117-280$ & $\begin{array}{l}\text { Mao et al. (2009, } \\
\text { 2010) }\end{array}$ \\
\hline & Microfluidization & 4 & 1.5 & $\begin{array}{l}\text { Corn oil, Miglyol } \\
812 \text { and orange } \\
\text { oil }\end{array}$ & $140-170$ & Qian et al. (2012) \\
\hline & Microfluidization & 5 & $1-10$ & Corn oil & $113-143$ & $\begin{array}{l}\text { Qian and McCle- } \\
\text { ments (2011) }\end{array}$ \\
\hline & $\begin{array}{l}\text { Microfluidization/ } \\
\text { solvent evapora- } \\
\text { tion }\end{array}$ & 0.3 & 0.5 & $\begin{array}{l}\beta \text {-Carotene in } \\
\text { hexane }\end{array}$ & $40-260$ & $\begin{array}{l}\text { Tan and Nakajima } \\
\text { (2005) }\end{array}$ \\
\hline & Microfluidization & 10 & 1 & $\begin{array}{l}\text { Thyme oil/Miglyol } \\
812 \text { oil }\end{array}$ & $160-176$ & Chang et al. (2012) \\
\hline & & & & Thyme oil/corn oil & $170-196$ & \\
\hline & Sonication & 15 & 5.6 & Flaxseed oil & 135 & Kentish et al. (2008) \\
\hline & $\begin{array}{l}\text { High-pressure } \\
\text { valve homog- } \\
\text { enizer }\end{array}$ & 3 & $4-12$ & $\begin{array}{l}\beta \text {-Carotene in } \\
\text { MCT oil }\end{array}$ & $160-184$ & Yuan et al. (2008) \\
\hline \multirow{3}{*}{$\begin{array}{l}\text { Polyoxyethylene } \\
\text { sorbitan mon- } \\
\text { ostearate }\end{array}$} & $\begin{array}{l}\text { Catastrophic phase } \\
\text { inversion }\end{array}$ & 20 & $10-20$ & Acetem $90-50 \mathrm{~K}$ & $100-200$ & $\begin{array}{l}\text { Bilbao-Sáinz et al. } \\
\text { (2010) }\end{array}$ \\
\hline & $\begin{array}{l}\text { High-pressure } \\
\text { valve homog- } \\
\text { enizer }\end{array}$ & 3 & $4-12$ & $\begin{array}{c}\beta \text {-Carotene in } \\
\text { MCT oil }\end{array}$ & $161-174$ & Yuan et al. (2008) \\
\hline & Microfluidization & 5 & 0.5 & Thyme oil/corn oil & $164-196$ & Ziani et al. (2011) \\
\hline \multirow{4}{*}{$\begin{array}{l}\text { Polyoxyethyl- } \\
\text { ene sorbitan } \\
\text { monooleate }\end{array}$} & Ultrasonication & 6 & $6-24$ & Basil oil & $29-41$ & Ghosh et al. (2013) \\
\hline & $\begin{array}{l}\text { High-pressure } \\
\text { valve homog- } \\
\text { enizer }\end{array}$ & $20 / 4 / 1$ & 1 & $\begin{array}{l}\text { PCL-liquid/ } \\
\text { Lipoid S-75/ } \alpha- \\
\text { tocopherol }\end{array}$ & 170 & Hoeller et al. (2009) \\
\hline & $\begin{array}{l}\text { High-pressure } \\
\text { valve homog- } \\
\text { enizer }\end{array}$ & 3 & $4-12$ & MCT oil & $157-178$ & Yuan et al. (2008) \\
\hline & Microfluidization & 10 & 1 & Lemon oil & $217-296$ & $\begin{array}{l}\text { Rao and McCle- } \\
\text { ments (2011) }\end{array}$ \\
\hline $\begin{array}{l}\text { Polyoxyethylene } \\
\text { lauryl ether }\end{array}$ & $\begin{array}{l}\text { Emulsification with } \\
\text { low energy }\end{array}$ & $40-80$ & $4-10$ & Isohexadecane & $26-1277$ & Peng et al. (2010) \\
\hline $\begin{array}{l}\text { Decaglycerol mon- } \\
\text { olaurate }\end{array}$ & $\begin{array}{l}\text { Microfluidization/ } \\
\text { high-pressure } \\
\text { valve homog- } \\
\text { enizer }\end{array}$ & $0.03,1$ & 1,10 & $\begin{array}{l}\beta \text {-Carotene in } \\
\text { sunflower oil }\end{array}$ & $115-279$ & $\begin{array}{l}\text { Mao et al. } \\
\qquad(2009,2010)\end{array}$ \\
\hline Sucrose palmitate & $\begin{array}{l}\text { Ultra-high-pressure } \\
\text { homogenization }\end{array}$ & $8 / 2,10$ & 1 & $\begin{array}{l}\text { D-limonene, trans- } \\
\text { cinnamaldehyde, } \\
\text { carvacrol in } \\
\text { sunflower oil }\end{array}$ & $130-168$ & Donsì et al. (2012) \\
\hline Sucrose laureate & $\begin{array}{l}\text { High-pressure } \\
\text { valve homog- } \\
\text { enizer }\end{array}$ & $20 / 4 / 1$ & 1 & $\begin{array}{l}\text { PCL-liquid/ } \\
\text { lipoid S-75 } \\
\text { / } \alpha \text {-tocopherol }\end{array}$ & 161 & Hoeller et al. (2009) \\
\hline $\begin{array}{l}\text { Sucrose monopal- } \\
\text { mitate }\end{array}$ & Microfluidization & 10 & $1-20$ & Lemon oil & $15-120$ & $\begin{array}{l}\text { Rao and McCle- } \\
\text { ments (2011) }\end{array}$ \\
\hline
\end{tabular}


Table 1 (continued)

\begin{tabular}{|c|c|c|c|c|c|c|}
\hline Type of emulsifier & $\begin{array}{l}\text { Homogenization } \\
\text { technique }\end{array}$ & $\begin{array}{l}\text { Percentage of oil } \\
\text { used }\end{array}$ & $\begin{array}{l}\text { Percentage } \\
\text { of emulsifier } \\
\text { used }\end{array}$ & Oil phase used & $\begin{array}{l}\text { Droplet size diam- } \\
\text { eter }(n m)\end{array}$ & Citation \\
\hline \multicolumn{7}{|l|}{ b. Ionic } \\
\hline \multirow[t]{3}{*}{ Pluronic F-68 } & \multirow[t]{3}{*}{ Ultrasonication } & \multirow[t]{3}{*}{25} & \multirow[t]{3}{*}{$1-2.5$} & Olive oil & 379 & $\begin{array}{l}\text { Wulff-Pérez et al. } \\
\text { (2009) }\end{array}$ \\
\hline & & & & Sesame oil & 368 & \\
\hline & & & & Soybean oil & 380 & \\
\hline \multirow{2}{*}{$\begin{array}{l}\text { Sodium dodecyl } \\
\text { sulfate }\end{array}$} & \multicolumn{3}{|l|}{ Microfluidization } & Silicone oil & 150 & Graves et al. (2005) \\
\hline & Microfluidization & 5 & $1-10$ & $\begin{array}{l}\text { Corn oil/octade- } \\
\text { cane }\end{array}$ & $92-131$ & $\begin{array}{l}\text { Qian and McCle- } \\
\text { ments (2011) }\end{array}$ \\
\hline \multicolumn{7}{|l|}{ c. Polysaccharide } \\
\hline \multirow{2}{*}{$\begin{array}{l}\text { Low-methoxyl pec- } \\
\text { tin, amidated low- } \\
\text { methoxyl pectin, } \\
\text { high-methoxyl } \\
\text { pectin }\end{array}$} & \multirow[t]{2}{*}{ Ultra-Turrax } & \multirow[t]{2}{*}{20} & \multirow[t]{2}{*}{$0.5-3$} & $\begin{array}{l}\text { Itraconazole in } \\
\text { chloroform }\end{array}$ & $200-900$ & $\begin{array}{l}\text { Burapapadh et al. } \\
\text { (2010) }\end{array}$ \\
\hline & & & & $\begin{array}{l}\text { Itraconazole in } \\
\text { Miglyol }{ }^{\circledR} 812\end{array}$ & $>2000$ & \\
\hline \multirow{4}{*}{$\begin{array}{l}\text { Succinylated waxy } \\
\text { maize starch/ } \\
\text { octenyl succinate } \\
\text { starch }\end{array}$} & \multirow[t]{2}{*}{$\begin{array}{l}\text { High-pressure } \\
\text { valve homog- } \\
\text { enizer }\end{array}$} & 10 & 15 & Neobee 1053 & 140 & Donsì et al. (2011) \\
\hline & & & & Neobee 1095 & 130 & \\
\hline & $\begin{array}{l}\text { Microfluidization/ } \\
\text { high-pressure } \\
\text { valve homog- } \\
\text { enizer }\end{array}$ & 1 & 10 & $\begin{array}{l}\beta \text {-Carotene in } \\
\text { sunflower oil }\end{array}$ & $262-674$ & Mao et al. (2010) \\
\hline & $\begin{array}{l}\text { High-pressure } \\
\text { valve homog- } \\
\text { enizer }\end{array}$ & 12 & 12 & $\begin{array}{l}\text { Peppermint oil/ } \\
\text { MCT oil }\end{array}$ & $184-228$ & Liang et al. (2012) \\
\hline $\begin{array}{l}\text { Maltodextrin/H- } \\
\text { Cap }\end{array}$ & $\begin{array}{l}\text { Microfluidization/ } \\
\text { sonication }\end{array}$ & $5,10,15$ & $30 / 10(40)$ & Fish oil & $174-274$ & Jafari et al. $(2007 a, b)$ \\
\hline \multicolumn{7}{|l|}{ d. Protein } \\
\hline Pea protein & $\begin{array}{l}\text { High-pressure } \\
\text { valve homog- } \\
\text { enizer }\end{array}$ & 8,10 & 3 & Sunflower oil & $184-218$ & Donsì et al. (2012) \\
\hline $\begin{array}{l}\text { Whey protein } \\
\text { isolate-maltodex- } \\
\text { trin conjugate }\end{array}$ & $\begin{array}{l}\text { Emulsification } \\
\text { with high energy/ } \\
\text { evaporation }\end{array}$ & $10,15,20,30$ & 1 & Thymol in hexane & $67-420$ & Shah et al. (2012) \\
\hline Soy protein & Microfluidization & 0.1 & 1 & $\begin{array}{l}\beta \text {-Carotene in } \\
\text { hexane }\end{array}$ & 196 & Chu et al. (2007) \\
\hline $\begin{array}{c}\text { Whey protein } \\
\text { concentrate }\end{array}$ & $\begin{array}{l}\text { Microfluidization; } \\
\text { microfluidization/ } \\
\text { sonication }\end{array}$ & $0.1 ; 20,25$ & $1 ; 10$ & $\begin{array}{l}\beta \text {-Carotene in hex- } \\
\text { ane; D-limonene }\end{array}$ & $145 ; 125-387$ & $\begin{array}{l}\text { Chu et al. (2007), } \\
\text { Jafari et al. (2006) }\end{array}$ \\
\hline \multirow[t]{4}{*}{$\begin{array}{l}\text { Whey protein } \\
\text { isolate }\end{array}$} & $\begin{array}{l}\text { High-pressure } \\
\text { valve homog- } \\
\text { enizer }\end{array}$ & $15,30,45$ & 4.3 & Pea nut oil & $146-236$ & $\begin{array}{l}\text { Cortés-Muñoz et al. } \\
\text { (2009) }\end{array}$ \\
\hline & $\begin{array}{l}\text { High-energy emul- } \\
\text { sification/solvent } \\
\text { evaporation }\end{array}$ & 10 & 1 & Corn oil & $75-121$ & $\begin{array}{l}\text { Lee and McClements } \\
\text { (2010) }\end{array}$ \\
\hline & $\begin{array}{l}\text { High-pressure } \\
\text { valve homog- } \\
\text { enizer }\end{array}$ & $0.03,1$ & 1,10 & $\begin{array}{l}\beta \text {-Carotene in } \\
\text { sunflower oil }\end{array}$ & $160-373$ & Mao et al. (2010) \\
\hline & $\begin{array}{l}\text { High-pressure } \\
\text { valve homog- } \\
\text { enizer }\end{array}$ & 20 & 4.5 & $\begin{array}{l}\alpha \text {-Tocopherol in } \\
\text { palm oil }\end{array}$ & $200-500$ & Relkin et al. (2011) \\
\hline
\end{tabular}


Table 1 (continued)

\begin{tabular}{|c|c|c|c|c|c|c|}
\hline Type of emulsifier & $\begin{array}{l}\text { Homogenization } \\
\text { technique }\end{array}$ & $\begin{array}{l}\text { Percentage of oil } \\
\text { used }\end{array}$ & $\begin{array}{l}\text { Percentage } \\
\text { of emulsifier } \\
\text { used }\end{array}$ & Oil phase used & $\begin{array}{l}\text { Droplet size diam- } \\
\text { eter }(\mathrm{nm})\end{array}$ & Citation \\
\hline \multirow[t]{5}{*}{$\begin{array}{l}\beta \text {-Lactoglobulin } \\
\quad(\beta-\lg )\end{array}$} & Microfluidization & 5 & $1-10$ & $\begin{array}{l}\text { Corn oil/octade- } \\
\text { cane }\end{array}$ & 162 & $\begin{array}{l}\text { Qian and McCle- } \\
\text { ments (2011) }\end{array}$ \\
\hline & $\begin{array}{l}\text { High-pressure } \\
\text { valve homog- } \\
\text { enizer }\end{array}$ & 20 & 1 & Soy oil & 350 & Sarkar et al. (2009) \\
\hline & \multirow[t]{3}{*}{ Microfluidization } & \multirow[t]{3}{*}{10} & \multirow[t]{3}{*}{1} & Corn oil & 181 & \multirow[t]{3}{*}{ Ahmed et al. (2012) } \\
\hline & & & & Miglyol ${ }^{\circledR} 812$ & 174 & \\
\hline & & & & Tributyrin & 1981 & \\
\hline Maize germ protein & $\begin{array}{c}\text { Combined aqueous } \\
\text { extraction-ultra- } \\
\text { filtration method }\end{array}$ & 5 & 3 & $\begin{array}{l}\text { Maize germ oil } \\
\text { bodies }\end{array}$ & 155 & $\begin{array}{l}\text { Nikiforidis et al. } \\
\text { (2011) }\end{array}$ \\
\hline \multirow[t]{3}{*}{ Sodium caseinate } & Microfluidization & $0.05-0.3$ & $0.5-5$ & $\begin{array}{l}\beta \text {-Carotene in } \\
\text { hexane }\end{array}$ & 17 & Chu et al. (2007) \\
\hline & Microfluidization & 5 & $1-10$ & $\begin{array}{l}\text { Corn oil/octade- } \\
\text { cane }\end{array}$ & 179 & $\begin{array}{l}\text { Qian and McCle- } \\
\text { ments (2011) }\end{array}$ \\
\hline & $\begin{array}{l}\text { High-pressure } \\
\text { valve homog- } \\
\text { enizer }\end{array}$ & 40 & 3.6 & $\begin{array}{l}\alpha \text {-Tocopherol/low } \\
\text { melting triacylg- } \\
\text { lycerols }\end{array}$ & $255-416,293-304$ & $\begin{array}{l}\text { Relkin et al. (2008, } \\
\text { 2009) }\end{array}$ \\
\hline
\end{tabular}

Fig. 2 An overview of nanoemulsions applications. Nanoemulsions are not only used in foods, they are now potent targets in healthcare delivery, cosmetics, polymers, among others. The physicochemical properties of nanoemulsions like stability, emulsification, solubility, ionic strength, $\mathrm{pH}$ and temperature are indicative of their functional purposes and utilization in several sectors other than the food industry

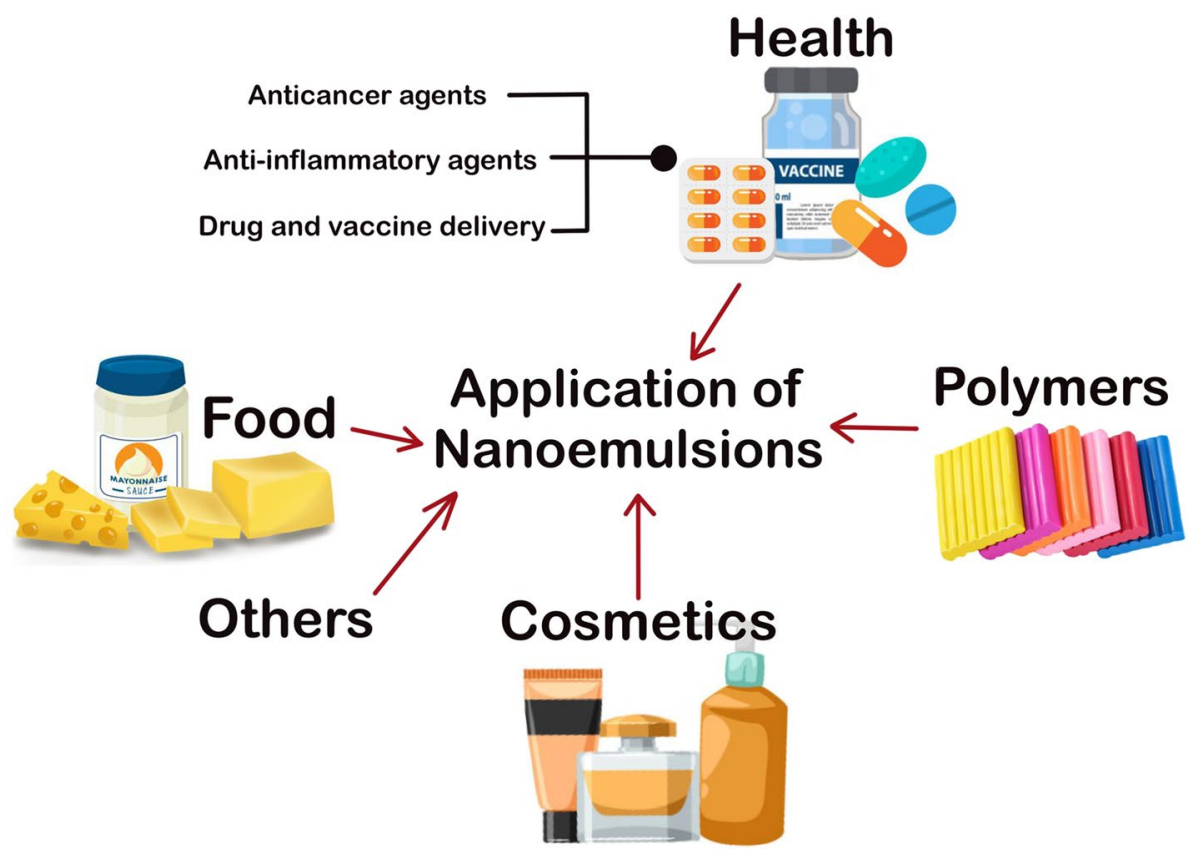

\section{Nanoemulsion applications}

Recent studies on the applications of nanoemulsions are described below, schematically presented in Fig. 2 and captured in Tables 2 and 3. The present coronavirus disease (COVID-19) pandemic has called for a more robust and holistic approach to solving health-related issues, the highest priority of the modern human civilization.

\section{Health}

\section{Drugs}

Nanoemulsions have the ability to dissolve nonpolar active compounds, a characteristic paramount to being choice of use as drug and bioactive compounds delivery systems. Both oral and parenteral delivery routes are employable, as the 


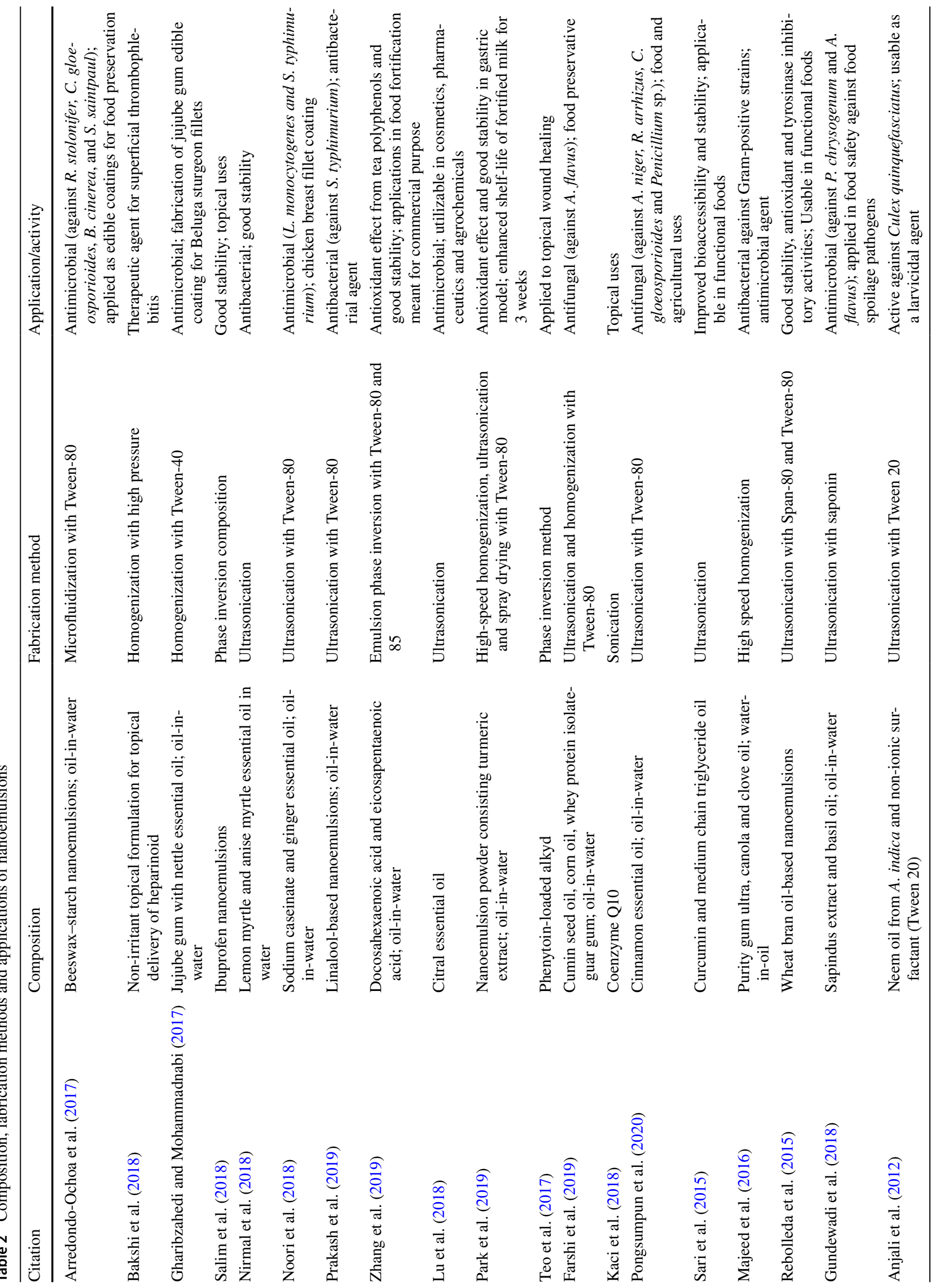




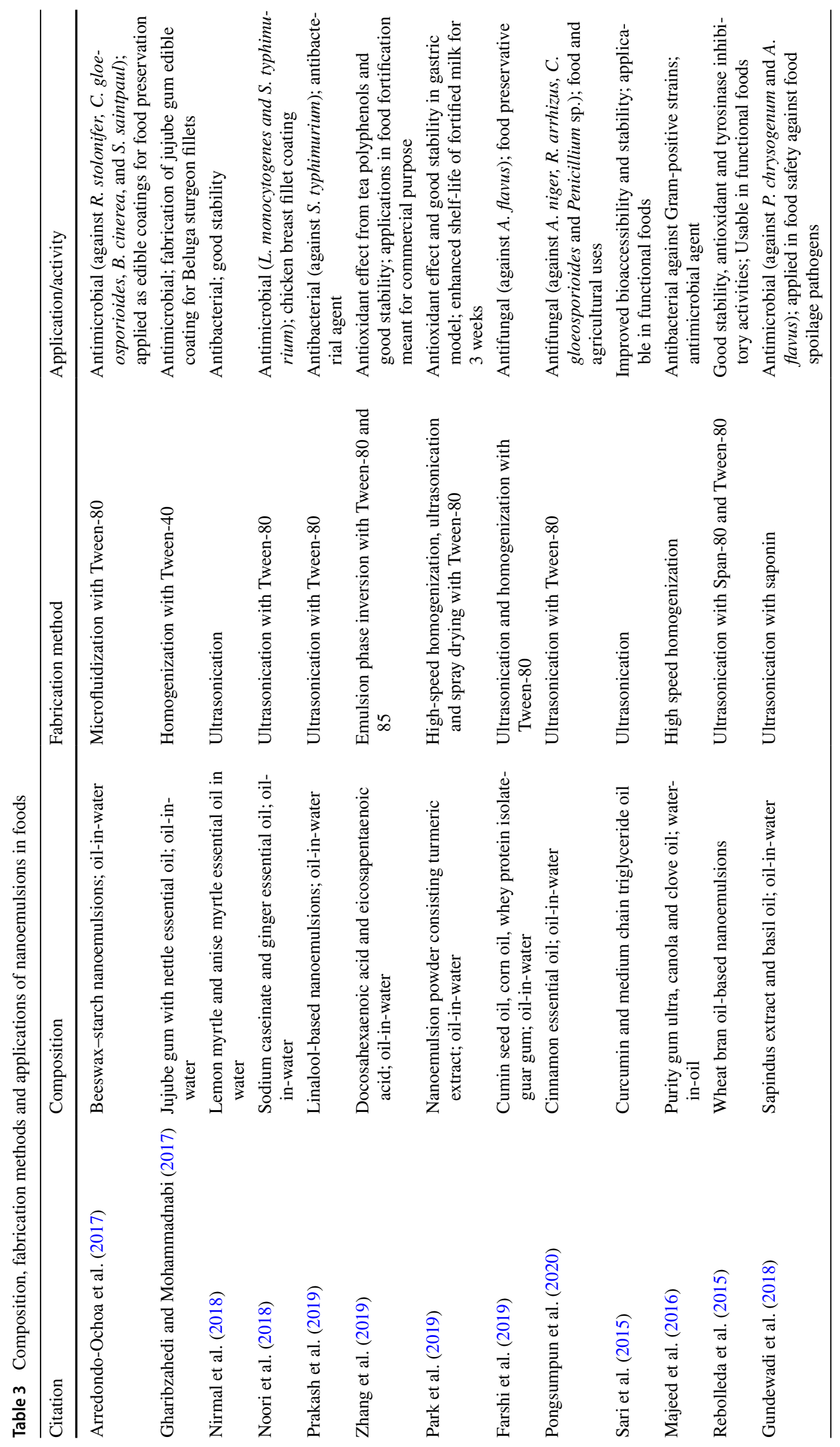


latter has been utilized in supplying required nutrients, controlled drug release, and vaccine delivery. Systemic antibacterial, antifungal, antiparasitic and antimicrobial activities of nanoemulsions have been reported on E. coli, S. aureus, Candida spp., Dermatophytes spp., Plasmodium bergheii, among others (Singh and Vingkar 2008; Mansour et al. 2009).

Nanoemulsions are more advantageous than the conventional emulsions and other systems since their droplet sizes are below the micrometers range, and thus they easily pass the stringency of intravenous administration of drugs. The parenteral administration of nanoemulsions employed in nutrition of vitamins and other bioactive substances, attest to the merits they possess over other systems as their transit time, absorption, and efficacy are highly improved, while drug toxicity is reduced. Therefore, they are perfect drug delivery systems for antimicrobials, diuretics, steroids, and hormones (Sonneville-Aubrun et al. 2004; Singh and Vingkar 2008; Quintão et al. 2013).

\section{Vaccines}

Of equal importance is the delivery of vaccines by nanoemulsions because it is gaining much wider attention from researchers. An attenuated organism is delivered onto the surface of a mucosal in order to elicit an immune response. Nanoemulsions are used in this case as adjuvants to deliver proteins onto the mucosal surface in order to instigate rapid absorption of antigen presenting cells. Physical adsorption, encapsulation (with or without coating and targeting), and conjugation (with chemical or targeting) mechanisms are often used to load antigens into nanocarriers. In any of the mechanisms, antigens are encapsulated in nanocarriers, while the nanoparticles degrade in vivo (Zhao et al. 2014). The vaccines can be very effective and spontaneous, irrespective of the site they are introduced to in the body. For instance, the immunity of genital mucosa might be guaranteed by administering the vaccines to the nasal mucosal (Berkowitz and Goddard 2009).

Vaccine adjuvants of oil/water emulsions have notable prospects, as found in $\mathrm{ASO} 3$ pandemic flu and recombinant HIV gp 120 nanoemulsion-mixed vaccines (Akhter et al. 2008; Reed et al. 2009). The validation of these studies are still warranted. Moreover, the composition of emulsion, antigenicity and adjuvant specificity are paramount factors to consider when designing nanoemulsion-based vaccines. The essence of this is to ensure safety and effective immunological benefits.

\section{Inflammation}

Nanoemulsions could also be employed in anti-inflammatory functions. Free radicals are released by enzymes, toxic metabolites of pathogens, and inflammation mediators such as polymorphonuclear lymphocytes, leading to chronic inflammation. These same enzymes and metabolites deprive host cells of their required nutrients for growth. However, the mix of emulsifiers and oils was reportedly significant in phytochemicals absorption and treatment of inflammatory bowel disease (IBD), i.e., Crohn's disease and ulcerative colitis (Yen et al. 2018) and periodontitis, a chronic inflammatory disease that erodes teeth's supporting structures (Aithal et al. 2018).

Inflammatory bowel disease (IBD) is often characterized with inflamed intestinal wall where the colonic and rectal mucosa are impacted. This is continuous for ulcerative colitis while it may be transmural and discontinuous in Crohn's disease. Host's lifestyle, genetic make-up, oxidative stress, pathogenic attack, immune responses, and drastic changes of inflammatory mediator levels are factors associated with IBD (Head and Jurenka 2003). Meanwhile, some studies have shown the usefulness of phytochemicals in treating periodontitis and IBD, including diterpenoid and quercetin, respectively (Geoghegan et al. 2010). Due to their low water solubility, they are less bio-available and are poorly absorbed orally. To increase their absorbability, both phytochemicals were improved with emulsions (Azuma et al. 2002).

\section{Cancer}

Abnormal cell proliferation due to genetic coding errors generate cancer cells. Active angiogenesis and vascular density occur in order to utilize the blood supply for tumor tissues growth, and is supported by a microenvironment of the extracellular matrix, adipocytes, pericytes, immune cells, and others (Ganta et al. 2014). The use of anticancer drugs may result in inadequate solubility, toxicity to noncancer cells, and poor selectivity of target cancer cells, while chemotherapy drugs may not be ideal in the long run due to their action on every form of proliferative cells, including hair follicles, bone marrow, red blood cells, gut epithelial cells, and lymphatic cells (Qiao et al. 2010; Mahato 2017).

Poor solubility and hydrophobicity of most anticancer drugs connote their inability to reach or effect their action on cancer cells (Sareen et al. 2012). This is where nanoemulsions are essential, as they proffer solubility to hydrophobic drugs and their stability. The resultant effect is that cancerous cells are selectively targeted earlier, leading to a high rate of successful cancer treatment. For instance, nanoemulsions could be engineered using specific ligands to target cells, tissues, or organs, all to improve the status quo in cancer therapy (Mahato 2017). Nanoparticles easily conjugate with multifunctional moieties, as found in nanoemulsions, aimed at drug delivery for cancer therapy via diagnostic means and imaging. Indeed, Tiwari et al. (2006) studied and used lipid-rich nanoemulsions containing fatty 
acids (omega- 3 and omega- 6 fatty acids, linoleic acid), nonglucose-based calories, and vitamins $\mathrm{E}$ and $\mathrm{K}$ as colloidal carriers for chemotherapeutic drugs, whilst using diagnostic and imaging techniques. Although the in vitro study was promising, the need for a validation and safety studies cannot be undermined. Table 2 offers more examples of nanoemulsion applications in healthcare delivery.

\section{Cosmetics and others}

Nanoemulsions could be traced to other applications such as complex matter developments and cosmetics, based on their liquid-liquid affinity to macromolecular moieties, minute size and large surface area. As building blocks of polymers, nanoemulsions could use their hydrophobic monomeric units in the droplets to generate polymers, with vast examples demonstrated in the studies of Asua (2002), Landfester (2006) and Gupta et al. (2016). Interestingly, from the development of varying protein shell structures with silicone oil-based nanoemulsions (Chang et al. 2008), amphiphilic photoreactive surfactants (de Oliveira et al. 2011), silica nanospheres (Wu et al. 2013), photoinduced and thermoreactive polymers or organogels (Helgeson et al. 2012), essential oils-based products (Barradas and e Silva 2020), suspended magnetic nanoparticles (Primo et al. 2007), to erythrocytelike composite hydrogels (An et al. 2013), nanoemulsions have been studied or applied.

Moreover, nanoemulsions could be used in composite and crystal formulations on the premise of size specificity and accuracy of active pharmaceutical ingredients and other products, involving a low energy-requiring process (Eral et al. 2014). Indeed, nanosized oil-loaded droplets ensure penetration of the stratum corneum, making them highly useful in alcohol-free perfume formulations (Rai et al. 2018; Barradas and e Silva 2020). Noteworthy to mention is that some oils used in nanoemulsions proffer some benefits that should not be undermined, and could be useful in the encapsulation of volatile components like aromatic compounds and essential oils.

On another note, the surface area and small size of nanoemulsion droplets increase their propensity to lesser viscousness, making them utilizable in the cosmetics sector as they could more efficiently deliver active substances to the skin. They are no flocculants, coalescing or creaming agents, and demonstrate little or no sediments, making their applications far more important than conventional emulsions in cosmetology. In this regard, Vellozia squamata and Opuntia ficusindica (L.) Mill hydroglycolic extracts were studied and applied to fabricate nanoemulsion-based moisturizers, creams, anti-ageing agents (Quintão et al. 2013; Ribeiro et al. 2015). Similarly, oils like coconut, polyethylene glycol octyl phenyl ether and polyethylene glycol hydrogenated castor oil were included in nanoemulsions for cosmeceutical applications (Pengon et al. 2018).

Furthermore, the use of nano-gel technique for transepidermal water loss minimization, dermal protection, and efficacious active ingredients penetration has been suggested for inclusion in moisteners, anti-ageing creams and various sun care formulations (Mansour et al. 2009). For instance, Kemira nano-gel is a nanoemulsion-based patented cosmetics system meant to attain skin smoothness by enhancing high penetrative capacity of active ingredients and dermal cells production (Guglielmini 2008). Another patented example is that of L'Oreal (Paris, France), using nanoemulsion-based phosphoric acid fatty acid esters in cosmetics and pharmaceutical products, among others (Shah et al. 2010). Table 2 presents more on the overview of use of nanoemulsions in cosmetics and other non-food applications.

\section{Food}

Nanoemulsions have proven quite useful in bioavailability, bioactivity, digestibility, stability, safety, quality, and sensory enhancements of food components and natural extracts, such as lycopene-solubilized and $\beta$-carotene-based nanoemulsions (Nedovic et al. 2011; Bakshi et al. 2018), based on their wide surface area and small droplets. To remain stable, formulation of nanoemulsions requires the presence of an emulsifier, often acting as not only an additive but a preservative of the food products and/or the active components. As an example, surface-active molecules were introduced during the fabrication of basil oil nanoemulsions, and were found to exert antimicrobial activity against certain food spoiling fungi, including Aspergillus flavus and Penicillium chrysogenum (Gundewadi et al. 2018). A similar study was carried out on avocado oil-based nanoemulsions stabilized with Quillaja saponins (QS) where thermal stability was reportedly increased as QS was incorporated in the emulsions, a merit in the cause of safe and sterile emulsion-based food products development (Teo et al. 2017; Riquelme et al. 2019).

The use of nanoemulsions to stabilize essential oils in foods also assist with overcoming their high volatility, hydrophobicity, and reactivity with other food components, which could reduce their applications in the food sector. The stabilized oils or nanoemulsions thus improve the antioxidant and antimicrobial activities of the processed essential oils, enhancing their compatibility, solubility, stability, physicochemical equilibrium, and behaviors (Lawrence and Rees 2000; Bai et al. 2016; Ghasemi et al. 2018; Prakash et al. 2019). Other studies that have applied nanoemulsions in foods include corn oil-based $\beta$-carotene nanoemulsions at $300 \mathrm{~nm}$ (Borba et al. 2019), sensory efficient nanoemulsions constituted with Brazilian propolis extracts (Seibert et al. 2019), improved digestible curcumin nanoemulsions, and 
nanoemulsion-based fortified beverages with vitamin D3 (Golfomitsou et al. 2018; Maurya and Aggarwal 2019). The possibilities of nanoemulsions in foods and food products seem limitless. More examples are presented in Table 3.

\section{Conclusion}

Based on their physicochemical and functional properties, nanoemulsions have very promising multisectorial uses in healthcare, food, polymer manufacturing and cosmetics industries. Therefore, they have gained prominent attention in the scientific community. Recent uses of beeswax-starch, jujube gum, sodium caseinate, turmeric extract, linalool, docosahexaenoic and eicosapentaenoic acid, cumin seed oil, whey protein isolate, and oils like cinnamon, lemon and anise myrtle essential oils in nanoemulsion formulations (Arredondo-Ochoa et al. 2017; Gharibzahedi and Mohammadnabi 2017; Nirmal et al. 2018; Noori et al. 2018; Prakash et al. 2019; Zhang et al. 2019; Park et al. 2019; Farshi et al. 2019; Pongsumpun et al. 2020) have shown high potentials in the food industry and for the general well being. They can also deliver phytochemicals and other bioactive components in the food industry (Mahmood et al. 2017). In addition, nanoemulsions also have multifarious prospects in non-food applications shown recently in inflammatory and periodontitis treatment, agrochemical, cosmetics and pharmaceutics, texturizing agents and creams, non-steroidal anti-inflammatory drug, drug and vaccine delivery, cosmeceutical applications and alcohol-free perfume formulations (Aithal et al. 2018; Teo et al. 2017; Bakshi et al. 2018; Lu et al. 2018; Kaci et al. 2018; Salim et al. 2018; Pengon et al. 2018; Rai et al. 2018; Shaker et al. 2019; Kumar et al. 2019; Barradas and e Silva 2020).

Formulating nanoemulsions often employ emulsifiers/ surfactants and nanoparticles, which have raised eyebrows regarding their safety because they accumulate both in the environment and in the human body (Bajpai et al. 2018). Any engineered nanoparticulates or materials attract some degree of attention due to limited comprehension of their mechanisms and health consequences, a major reason to delay further implementation of nanotechnology in the food industry (Loira et al. 2020). For instance, long-term exposure to silver nanoparticles could lead to cell damage and inflammation via oxidative stress reactions (Gaillet and Rouanet 2015; Smolkova et al. 2015). Thus, it is required that the safety of nanoparticles-based systems such as nanoemulsions must be ascertained, along with their physicochemical characteristics in order to help with tactile conclusions and policies of regulatory bodies.

In addition, the methods and conditions associated with nanoemulsions production will affect their stability and other physicochemical properties, with corresponding impacts on their applications. Hence, specificity is key. Solubility, availability, activity, acceptability and polarity would be noteworthy concerns to look at, when developing nanoemulsions. Considering all these factors would inadvertently affect the cost of production for much larger commercial applications. Conclusively, nanoemulsions indeed could be utilized in several sectors other than the food industry.

Acknowledgements The author expresses his profound gratitude to the Institute of Research and Development, Duy Tan University, Da Nang, Vietnam.

Authors' contributions TJA conceptualized, researched, compiled and analyzed data, as well as drafted, edited and revised the manuscript.

Funding No external funding was received for this work.

Availability of data and material No dataset were generated in this study.

Code availability Not applicable.

\section{Compliance with ethical standards}

Conflict of interest The author has no conflicts of interest to declare that are relevant to the content of this article.

Ethical approval This article does not contain any studies with human participants or animals performed by the author.

Consent to participate Not applicable.

Consent for publication Not applicable.

\section{References}

Adjonu R, Doran G, Torley P et al (2014) Whey protein peptides as components of nanoemulsions: A review of emulsifying and biological functionalities. J Food Eng 122:15-27. https://doi.org/10. 1016/j.jfoodeng.2013.08.034

Ahmed K, Li Y, McClements DJ et al (2012) Nanoemulsion-and emulsion-based delivery systems for curcumin: Encapsulation and release properties. Food Chem 132(2):799-807. https://doi.org/ 10.1016/j.foodchem.2011.11.039

Aithal GC, Nayak UY, Mehta C et al (2018) Localized in situ nanoemulgel drug delivery system of quercetin for periodontitis: development and computational simulations. Molecules 23(6):1363. https://doi.org/10.3390/molecules23061363

Akhter S, Jain GK, Ahmad FJ et al (2008) Investigation of nanoemulsion system for transdermal delivery of domperidone: ex-vivo and in vivo studies. Curr Nanosci 4(4):381-390. https://doi.org/ $10.2174 / 157341308786306071$

An HZ, Safai ER, Eral HB et al (2013) Synthesis of biomimetic oxygen-carrying compartmentalized microparticles using flow lithography. Lab Chip 13(24):4765-4774. https://doi.org/10. 1039/C3LC50610J

An Y, Yan X, Li B et al (2014) Microencapsulation of capsanthin by self-emulsifying nanoemulsions and stability evaluation. Eur Food Res Technol 239(6):1077-1085. https://doi.org/10.1007/ s00217-014-2328-3 
Anjali CH, Sharma Y, Mukherjee A et al (2012) Neem oil (Azadirachta indica) nanoemulsion - a potent larvicidal agent against $C$ ulex quinquefasciatus. Pest Manag Sci 68(2):158-163. https://doi.org/ $10.1002 /$ ps. 2233

Arredondo-Ochoa T, García-Almendárez BE, Escamilla-García M et al (2017) Physicochemical and antimicrobial characterization of beeswax-starch food-grade nanoemulsions incorporating natural antimicrobials. Int J Mol Sci 18(12):2712. https://doi.org/10. 3390/ijms 18122712

Artiga-Artigas M, Guerra-Rosas MI, Morales-Castro J et al (2018) Influence of essential oils and pectin on nanoemulsion formulation: a ternary phase experimental approach. Food hydrocoll 81:209-219. https://doi.org/10.1016/j.foodhyd.2018.03.001

Ashaolu TJ (2020a) Applications of soy protein hydrolysates in the emerging functional foods: a review. Int J Food Sci Technol 55(2):421-428. https://doi.org/10.1111/ijfs.14380

Ashaolu TJ (2020b) Soy bioactive peptides and the gut microbiota modulation. Appl Microbiol Biotechnol 104:9009-9017. https:// doi.org/10.1007/s00253-020-10799-2

Asua JM (2002) Miniemulsion polymerization. Prog Polym Sci 27(7):1283-1346. https://doi.org/10.1016/S0079-6700(02) 00010-2

Aziz ZAA, Mohd-Nasir H, Setapar M et al (2019) Role of nanotechnology for design and development of cosmeceutical: application in makeup and skin care. Front Chem 7:739. https://doi.org/10. 3389/fchem.2019.00739

Azmi NAN, Elgharbawy AA, Motlagh SR et al (2019) Nanoemulsions: factory for food, pharmaceutical and cosmetics. Processes 7(9):617. https://doi.org/10.3390/pr7090617

Azuma K, Ippoushi K, Ito H et al (2002) Combination of lipids and emulsifiers enhances the absorption of orally administered quercetin in rats. J Agric Food Chem 50(6):1706-1712. https:// doi.org/10.1021/jf0112421

Bai L, Huan S, Gu J et al (2016) Fabrication of oil-in-water nanoemulsions by dual-channel microfluidization using natural emulsifiers: saponins, phospholipids, proteins, and polysaccharides. Food Hydrocoll 61:703-711. https://doi.org/10.1016/j.foodhyd. 2016.06.035

Bajpai VK, Kamle M, Shukla S et al (2018) Prospects of using nanotechnology for food preservation, safety, and security. J Food Drug Anal 26(4):1201-1214. https://doi.org/10.1016/j.jfda.2018. 06.011

Bakshi P, Jiang Y, Nakata T et al (2018) Formulation development and characterization of nanoemulsion-based formulation for topical delivery of heparinoid. J Pharm Sci 107(11):2883-2890. https:// doi.org/10.1016/j.xphs.2018.07.015

Barradas TN, e Silva KGDH, (2020) Nanoemulsions of essential oils to improve solubility, stability and permeability: a review. Environ Chem Lett 1-19. https://doi.org/10.1007/s10311-020-01142-2

Berkowitz AC, Goddard DM (2009) Novel drug delivery systems: future directions. J Neurosci Nurs 41(2):115-120. https://doi. org/10.1097/jnn.0b013e318193458b

Bilbao-Sáinz C, Avena-Bustillos RJ, Wood DF et al (2010) Nanoemulsions prepared by a low-energy emulsification method applied to edible films. J Agric Food Chem 58(22):11932-11938. https:// doi.org/10.1021/jf102341r

Borba CM, Tavares MN, Macedo LP et al (2019) Physical and chemical stability of $\beta$-carotene nanoemulsions during storage and thermal process. Food Res Int 121:229-237. https://doi.org/10.1016/j. foodres.2019.03.045

Bouchemal K, Briançon S, Perrier E et al (2004) Nano-emulsion formulation using spontaneous emulsification: solvent, oil and surfactant optimisation. Int J pharm 280(1-2):241-251. https://doi. org/10.1016/j.ijpharm.2004.05.016
Burapapadh K, Kumpugdee-Vollrath M, Chantasart D et al (2010) Fabrication of pectin-based nanoemulsions loaded with itraconazole for pharmaceutical application. Carb Polym 82(2):384-393. https://doi.org/10.1016/j.carbpol.2010.04.071

Chang CB, Knobler CM, Gelbart WM et al (2008) Curvature dependence of viral protein structures on encapsidated nanoemulsion droplets. ACS Nano 2(2):281-286. https://doi.org/10.1021/ nn700385z

Chang Y, McLandsborough L, McClements DJ (2012) Physical properties and antimicrobial efficacy of thyme oil nanoemulsions: influence of ripening inhibitors. J Agric Food Chem 60(48):12056-12063. https://doi.org/10.1021/jf304045a

Chowdhury P, Gogoi M, Borchetia S et al (2017) Nanotechnology applications and intellectual property rights in agriculture. Environ Chem Lett 15(3):413-419. https://doi.org/10.1007/ s10311-017-0632-4

Christiansen KF, Vegarud G, Langsrud T et al (2004) Hydrolyzed whey proteins as emulsifiers and stabilizers in high-pressure processed dressings. Food Hydrocoll 18(5):757-767. https:// doi.org/10.1016/j.foodhyd.2003.12.002

Cortés-Muñoz M, Chevalier-Lucia D, Dumay E (2009) Characteristics of submicron emulsions prepared by ultra-high pressure homogenisation: effect of chilled or frozen storage. Food hydrocoll 23(3):640-654. https://doi.org/10.1016/j.foodhyd. 2008.07.023

Dasgupta N, Ranjan S, Gandhi M (2019a) Nanoemulsion ingredients and components. Environ Chem Lett 17(2):917-928. https://doi. org/10.1007/s10311-018-00849-7

Dasgupta N, Ranjan S, Gandhi M (2019b) Nanoemulsions in food: market demand. Environ Chem Lett 17(2):1003-1009. https:// doi.org/10.1007/s10311-019-00856-2

de Oliveira RJ, Brown P, Correia GB et al (2011) Photoreactive surfactants: a facile and clean route to oxide and metal nanoparticles in reverse micelles. Langmuir 27(15):9277-9284. https://doi.org/ $10.1021 / \mathrm{la} 202147 \mathrm{~h}$

Donsì F, Annunziata M, Vincensi M et al (2012) Design of nanoemulsion-based delivery systems of natural antimicrobials: effect of the emulsifier. J Biotechnol 159(4):342-350. https://doi.org/10. 1016/j.jbiotec.2011.07.001

Donsì F, Wang Y, Huang Q (2011) Freeze-thaw stability of lecithin and modified starch-based nanoemulsions. Food Hydrocoll 25(5):1327-1336. https://doi.org/10.1016/j.foodhyd.2010.12.008

Eral HB, López-Mejías V, O'Mahony M et al (2014) Biocompatible alginate microgel particles as heteronucleants and encapsulating vehicles for hydrophilic and hydrophobic drugs. Crystal Growth Des 14(4):2073-2082. https://doi.org/10.1021/cg500250e

Farshi P, Tabibiazar M, Ghorbani M et al (2019) Whey protein isolateguar gum stabilized cumin seed oil nanoemulsion. Food Biosci 28:49-56. https://doi.org/10.1016/j.fbio.2019.01.011

Feng J, Zhang Q, Liu Q et al (2018) Application of nanoemulsions in formulation of pesticides. In: Nanoemulsions. Academic Press, pp 379-413. https://doi.org/10.1016/B978-0-12-811838-2. 00012-6

Foegeding EA, Davis JP, Doucet D et al (2002) Advances in modifying and understanding whey protein functionality. Trends Food Sci Technol 13(5):151-159. https://doi.org/10.1016/s0924-2244(02) 00111-5

Gaillet S, Rouanet JM (2015) Silver nanoparticles: their potential toxic effects after oral exposure and underlying mechanisms-a review. Food Chem Toxicol 77:58-63. https://doi.org/10.1016/j. fct.2014.12.019

Ganta S, Talekar M, Singh A et al (2014) Nanoemulsions in translational research-opportunities and challenges in targeted cancer therapy. AAPS PharmSciTech 15(3):694-708. https://doi.org/10. 1208/s12249-014-0088-9 
Geoghegan F, Wong RWK, Rabie ABM (2010) Inhibitory effect of quercetin on periodontal pathogens in vitro. Phytother Res 24(6):817-820. https://doi.org/10.1002/ptr.3014

Gharibzahedi SMT, Mohammadnabi S (2017) Effect of novel bioactive edible coatings based on jujube gum and nettle oil-loaded nanoemulsions on the shelf-life of Beluga sturgeon fillets. Int $\mathbf{J}$ Biol Macromol 95:769-777. https://doi.org/10.1016/j.ijbiomac. 2016.11.119

Ghasemi S, Jafari SM, Assadpour E et al (2018) Nanoencapsulation of d-limonene within nanocarriers produced by pectin-whey protein complexes. Food Hydrocoll 77:152-162. https://doi.org/10. 1016/j.foodhyd.2017.09.030

Ghosh V, Mukherjee A, Chandrasekaran N (2013) Ultrasonic emulsification of food-grade nanoemulsion formulation and evaluation of its bactericidal activity. Ultrason Sonochem 20(1):338-344. https://doi.org/10.1016/j.ultsonch.2012.08.010

Golfomitsou I, Mitsou E, Xenakis A et al (2018) Development of food grade $\mathrm{O} / \mathrm{W}$ nanoemulsions as carriers of vitamin $\mathrm{D}$ for the fortification of emulsion based food matrices: a structural and activity study. J Mol Liq 268:734-742

Gordon EM, Cornelio GH, Lorenzo CC et al (2003) First clinical experience using a 'pathotropic' injectable retroviral vector (Rexin$\mathrm{G})$ as intervention for stage IV pancreatic cancer. Int J Oncol 24(1):177-185. https://doi.org/10.3892/ijo.24.1.177

Graves S, Meleson K, Wilking J et al (2005) Structure of concentrated nanoemulsions. J Chem Phys 122(13):134703. https://doi.org/ $10.1063 / 1.1874952$

Guglielmini G (2008) Nanostructured novel carrier for topical application. Clin Dermatol 26(4):341-346. https://doi.org/10.1016/j. clindermatol.2008.05.004

Gundewadi G, Sarkar DJ, Rudra SG et al (2018) Preparation of basil oil nanoemulsion using Sapindus mukorossi pericarp extract: Physico-chemical properties and antifungal activity against food spoilage pathogens. Indus Crops Prod 125:95-104. https://doi. org/10.1016/j.indcrop.2018.08.076

Gupta A, Eral HB, Hatton TA et al (2016) Nanoemulsions: formation, properties and applications. Soft Mat 12(11):2826-2841. https:// doi.org/10.1039/C5SM02958A

Gurpreet K, Singh SK (2018) Review of nanoemulsion formulation and characterization techniques. Indian J Pharm Sci 80(5):781-789. https://doi.org/10.4172/pharmaceutical-sciences.1000422

Head KA, Jurenka JS (2003) Inflammatory bowel disease part 1: ulcerative colitis-pathophysiology and conventional and alternative treatment options. Altern Med Rev 8(3):247-283

Helgeson ME, Moran SE, An HZ et al (2012) Mesoporous organohydrogels from thermogelling photocrosslinkable nanoemulsions. Nat Mater 11(4):344-352. https://doi.org/10.1038/nmat3248

Hoeller S, Sperger A, Valenta C (2009) Lecithin based nanoemulsions: a comparative study of the influence of non-ionic surfactants and the cationic phytosphingosine on physicochemical behaviour and skin permeation. Int J Pharm 370(1-2):181-186. https://doi.org/ 10.1016/j.ijpharm.2008.11.014

Jafari SM, He Y, Bhandari B (2007a) Optimization of nano-emulsions production by microfluidization. Eur Food Res Technol 225(56):733-741. https://doi.org/10.1007/s00217-006-0476-9

Jafari SM, He Y, Bhandari B (2007b) Production of sub-micron emulsions by ultrasound and microfluidization techniques. J Food Eng 82(4):478-488. https://doi.org/10.1016/j.foodeng.2007.03.007

Jaiswal M, Dudhe R, Sharma PK (2015) Nanoemulsion: an advanced mode of drug delivery system. 3 Biotech 5(2):123-127. https:// doi.org/10.1007/s13205-014-0214-0

Kaci M, Belhaffef A, Meziane S et al (2018) Nanoemulsions and topical creams for the safe and effective delivery of lipophilic antioxidant coenzyme Q10. Colloids Surf B Biointerf 167:165-175. https://doi.org/10.1016/j.colsurfb.2018.04.010
Kaul S, Gulati N, Verma D et al (2018) Role of nanotechnology in cosmeceuticals: a review of recent advances. J Pharm 3420204. https://doi.org/10.1155/2018/3420204

Kentish S, Wooster TJ, Ashokkumar M et al (2008) The use of ultrasonics for nanoemulsion preparation. Innov Food Sci Emerg Technol 9(2):170-175. https://doi.org/10.1016/j.ifset.2007.07. 005

Kim CK, Cho YJ, Gao ZG (2001) Preparation and evaluation of biphenyl dimethyl dicarboxylate microemulsions for oral delivery. J Control Rel 70(1-2):149-155. https://doi.org/10.1016/s01683659(00)00343-6

Kumar DL, Sarkar P (2018) Encapsulation of bioactive compounds using nanoemulsions. Environ Chem Lett 16(1):59-70. https:// doi.org/10.1007/s10311-017-0663-x

Kumar M, Bishnoi RS, Shukla AK et al (2019) Techniques for formulation of nanoemulsion drug delivery system: a review. Prev Nutr Food Sci 24(3):225. https://doi.org/10.3746/pnf.2019.24.3.225

Landfester K (2006) Synthesis of colloidal particles in miniemulsions. Annu Rev Mater Res 36:231-279. https://doi.org/10.1146/annur ev.matsci.36.032905.091025

Lawrence MJ, Rees GD (2000) Microemulsion-based media as novel drug delivery systems. Adv Drug Del Rev 45(1):89-121. https:// doi.org/10.1016/S0169-409X(00)00103-4

Lee SJ, McClements DJ (2010) Fabrication of protein-stabilized nanoemulsions using a combined homogenization and amphiphilic solvent dissolution/evaporation approach. Food Hydrocoll 24(6-7):560-569. https://doi.org/10.1016/j.foodhyd.2010.02.002

Liang R, Xu S, Shoemaker CF et al (2012) Physical and antimicrobial properties of peppermint oil nanoemulsions. J Agric Food Chem 60(30):7548-7555. https://doi.org/10.1021/jf301129k

Loira I, Morata A, Escott C et al (2020) Applications of nanotechnology in the winemaking process. Eur Food Res Technol 1-9. https://doi.org/10.1007/s00217-020-03519-7

Lovelyn C, Attama AA (2011) Current state of nanoemulsions in drug delivery. J Biomater Nanobiotechnol 2(05):626. https://doi.org/ 10.4236/jbnb.2011.225075

Lu WC, Huang DW, Wang CC et al (2018) Preparation, characterization, and antimicrobial activity of nanoemulsions incorporating citral essential oil. J Food Drug Anal 26(1):82-89. https://doi. org/10.1016/j.jfda.2016.12.018

Macedo JP, Fernandes LL, Formiga FR et al (2006) Micro-emultocrit technique: a valuable tool for determination of critical HLB value of emulsions. AAPS PharmSciTech 7(1):146-152. https://doi. org/10.1208/pt070121

Mahato R (2017) Nanoemulsion as targeted drug delivery system for cancer therapeutics. J Pharm Sci pharmacol 3(2):83-97. https:// doi.org/10.1166/jpsp.2017.1082

Mahmood Z, Jahangir M, Liaquat M et al (2017) Potential of nanoemulsions as phytochemical delivery system for food preservation. Pak J Pharm Sci 30(6):2259-2263

Majeed H, Liu F, Hategekimana J et al (2016) Bactericidal action mechanism of negatively charged food grade clove oil nanoemulsions. Food Chem 197:75-83. https://doi.org/10.1016/j.foodc hem.2015.10.015

Mansour HM, Rhee YS, Wu X (2009) Nanomedicine in pulmonary delivery. Int J Nanomed 4:299

Mao L, Xu D, Yang J et al (2009) Effects of small and large molecule emulsifiers on the characteristics of $\beta$-carotene nanoemulsions prepared by high pressure homogenization. Food Technol Biotechnol 47(3):336-342

Mao L, Yang J, Xu D et al (2010) Effects of homogenization models and emulsifiers on the physicochemical properties of $\beta$-carotene nanoemulsions. J Dispers Sci Technol 31(7):986-993. https:// doi.org/10.1080/01932690903224482 
Maurya VK, Aggarwal M (2019) A phase inversion based nanoemulsion fabrication process to encapsulate vitamin D3 for food applications. J Steroid Biochem Mol Biol 190:88-98. https://doi.org/ 10.1016/j.jsbmb.2019.03.021

McClements DJ, Jafari SM (2018) General aspects of nanoemulsions and their formulation. In: Nanoemulsions. Academic Press, pp 3-20. https://doi.org/10.1016/B978-0-12-811838-2.00001-1

McClements DJ, Bai L, Chung C (2017) Recent advances in the utilization of natural emulsifiers to form and stabilize emulsions. Ann Rev Food Sci Technol 8:205-236. https://doi.org/10.1146/annur ev-food-030216-030154

Mishra RK, Soni GC, Mishra RP (2014) A review article on nanoemulsion. World J Pharm Pharm Sci 3(9):258-274. https://doi.org/10. 7897/2230-8407.0913

Mohammadi A, Jafari SM, Esfanjani AF et al (2016) Application of nano-encapsulated olive leaf extract in controlling the oxidative stability of soybean oil. Food Chem 190:513-519. https://doi. org/10.1016/j.foodchem.2015.05.115

Nedovic V, Kalusevic A, Manojlovic V et al (2011) An overview of encapsulation technologies for food applications. Proc Food Sci 1:1806-1815. https://doi.org/10.1016/j.profoo.2011.09.265

Nikiforidis CV, Karkani OA, Kiosseoglou V (2011) Exploitation of maize germ for the preparation of a stable oil-body nanoemulsion using a combined aqueous extraction-ultrafiltration method. Food Hydrocoll 25(5):1122-1127. https://doi.org/10.1016/j. foodhyd.2010.10.009

Nirmal NP, Mereddy R, Li L et al (2018) Formulation, characterisation and antibacterial activity of lemon myrtle and anise myrtle essential oil in water nanoemulsion. Food Chem 254:1-7. https:// doi.org/10.1016/j.foodchem.2018.01.173

Noori S, Zeynali F, Almasi H (2018) Antimicrobial and antioxidant efficiency of nanoemulsion-based edible coating containing ginger (Zingiber officinale) essential oil and its effect on safety and quality attributes of chicken breast fillets. Food Control 84:312320. https://doi.org/10.1016/j.foodcont.2017.08.015

O'Sullivan JJ, Drapala KP, Kelly AL et al (2018) The use of inline high-shear rotor-stator mixing for preparation of high-solids milk protein-stabilised oil-in-water emulsions with different protein: fat ratios. J Food Eng 222:218-225. https://doi.org/10.1016/j. jfoodeng.2017.10.015

Park SJ, Hong SJ, Garcia CV et al (2019) Stability evaluation of turmeric extract nanoemulsion powder after application in milk as a food model. J Food Eng 259:12-20. https://doi.org/10.1016/j. jfoodeng.2019.04.011

Peng LC, Liu CH, Kwan CC et al (2010) Optimization of water-in-oil nanoemulsions by mixed surfactants. Colloids Surf A: Physicochem Eng Asp 370(1-3):136-142. https://doi.org/10.1016/j.colsu rfa.2010.08.060

Pengon S, Chinatangkul N, Limmatvapirat C et al (2018) The effect of surfactant on the physical properties of coconut oil nanoemulsions. Asian J Pharm Sci 13(5):409-414. https://doi.org/10. 1016/j.ajps.2018.02.005

Pongsumpun P, Iwamoto S, Siripatrawan U (2020) Response surface methodology for optimization of cinnamon essential oil nanoemulsion with improved stability and antifungal activity. Ultrasonics Sonochem 60:104604. https://doi.org/10.1016/j.ultsonch. 2019.05.021

Prakash A, Vadivel V, Rubini D et al (2019) Antibacterial and antibiofilm activities of linalool nanoemulsions against Salmonella typhimurium. Food Biosci 28:57-65. https://doi.org/10.1016/j. fbio.2019.01.018

Primo FL, Michieleto L, Rodrigues MA et al (2007) Magnetic nanoemulsions as drug delivery system for Foscan ${ }^{\circledR}$ : skin permeation and retention in vitro assays for topical application in photodynamic therapy (PDT) of skin cancer. J Mag Mag Mat 311(1):354-357. https://doi.org/10.1016/j.jmmm.2006.10.1183
Qian C, McClements DJ (2011) Formation of nanoemulsions stabilized by model food-grade emulsifiers using high-pressure homogenization: factors affecting particle size. Food Hydrocoll 25(5):1000-1008. https://doi.org/10.1016/j.foodhyd.2010.09.017

Qian C, Decker EA, Xiao H et al (2012) Nanoemulsion delivery systems: influence of carrier oil on $\beta$-carotene bioaccessibility. Food Chem 135(3):1440-1447. https://doi.org/10.1016/j.foodchem. 2012.06.047

Qiao W, Wang B, Wang Y et al (2010) Cancer therapy based on nanomaterials and nanocarrier systems. J Nanomaterials. https://doi. org/10.1155/2010/796303

Quintão FJ, Tavares RS, Vieira-Filho SA et al (2013) Hydroalcoholic extracts of Vellozia squamata: study of its nanoemulsions for pharmaceutical or cosmetic applications. Rev Bras Farmacogn 23(1):101-107. https://doi.org/10.1590/S0102-695X201300 5000001

Rai VK, Mishra N, Yadav KS et al (2018) Nanoemulsion as pharmaceutical carrier for dermal and transdermal drug delivery: formulation development, stability issues, basic considerations and applications. J Control Rel 270:203-225. https://doi.org/10. 1016/j.jconrel.2017.11.049

Rao J, McClements DJ (2011) Food-grade microemulsions, nanoemulsions and emulsions: fabrication from sucrose monopalmitate \& lemon oil. Food hydrocoll 25(6):1413-1423. https://doi.org/10. 1016/j.foodhyd.2011.02.004

Rebolleda S, Sanz MT, Benito JM et al (2015) Formulation and characterisation of wheat bran oil-in-water nanoemulsions. Food Chem 167:16-23. https://doi.org/10.1016/j.foodchem.2014.06.097

Reed SG, Bertholet S, Coler RN et al (2009) New horizons in adjuvants for vaccine development. Trends Immunol 30(1):23-32. https:// doi.org/10.1016/j.it.2008.09.006

Relkin P, Jung JM, Ollivon M (2009) Factors affecting vitamin degradation in oil-in-water nano-emulsions. J Therm Anal Cal 98(1):13. https://doi.org/10.1007/s10973-009-0340-9

Relkin P, Shukat R, Bourgaux C et al (2011) Nanostructures and polymorphisms in protein stabilised lipid nanoparticles, as food bioactive carriers: contribution of particle size and adsorbed materials. Proc Food Sci 1:246-250. https://doi.org/10.1016/j. profoo.2011.09.039

Relkin P, Yung JM, Kalnin D et al (2008) Structural behaviour of lipid droplets in protein-stabilized nano-emulsions and stability of $\alpha$-tocopherol. Food Biophys 3(2):163-168. https://doi.org/10. 1007/s11483-008-9064-9

Research and Market (2018) Global nanotechnology market outlook 2024. Report ID: 4991720. https://www.researchandmarkets. com/reports/4536705/global-nanotechnology-market-outlook2018-2024. Web assessed on 22nd December 2020.

Ribeiro RCDA, Barreto SMAG, Ostrosky EA et al (2015) Production and characterization of cosmetic nanoemulsions containing Opuntia ficus-indica (L.) Mill extract as moisturizing agent. Molecules 20(2):2492-2509. https://doi.org/10.3390/molecules2 0022492

Riquelme N, Zúñiga RN, Arancibia C (2019) Physical stability of nanoemulsions with emulsifier mixtures: replacement of tween 80 with quillaja saponin. LWT 111:760-766. https://doi.org/10. 1016/j.lwt.2019.05.067

Roca-Saavedra P, Mendez-Vilabrille V, Miranda JM et al (2018) Food additives, contaminants and other minor components: effects on human gut microbiota - a review. J Physiol Biochem 74(1):69-83. https://doi.org/10.1007/s13105-017-0564-2

Saini A, Panwar D, Panesar PS et al (2020) Encapsulation of functional ingredients in lipidic nanocarriers and antimicrobial applications: a review. Environ Chem Lett 1-28. https://doi.org/10.1007/ s10311-020-01109-3

Salim N, García-Celma MJ, Escribano E et al (2018) Formation of nanoemulsion containing ibuprofen by PIC method for topical delivery. 
Mat Today: Proc 5:172-179. https://doi.org/10.1016/j.matpr.2018. 08.062

Sareen S, Mathew G, Joseph L (2012) Improvement in solubility of poor water-soluble drugs by solid dispersion. Int J Pharm Invest 2(1):12. https://doi.org/10.4103/2230-973X.96921

Sari TP, Mann B, Kumar R et al (2015) Preparation and characterization of nanoemulsion encapsulating curcumin. Food Hydrocoll 43:540-546. https://doi.org/10.1016/j.foodhyd.2014.07.011

Sarkar A, Goh KK, Singh RP et al (2009) Behaviour of an oil-in-water emulsion stabilized by $\beta$-lactoglobulin in an in vitro gastric model. Food Hydrocoll 23(6):1563-1569. https://doi.org/10.1016/j.foodh yd.2008.10.014

Seibert JB, Bautista-Silva JP, Amparo TR et al (2019) Development of propolis nanoemulsion with antioxidant and antimicrobial activity for use as a potential natural preservative. Food Chem 287:61-67. https://doi.org/10.1016/j.foodchem.2019.02.078

Shah B, Ikeda S, Davidson PM et al (2012) Nanodispersing thymol in whey protein isolate-maltodextrin conjugate capsules produced using the emulsion — evaporation technique. J Food Eng 113(1):7986. https://doi.org/10.1016/j.jfoodeng.2012.05.019

Shah P, Bhalodia D, Shelat P (2010) Nanoemulsion: a pharmaceutical review. Syst Rev Pharm. https://doi.org/10.4103/0975-8453.59509

Shah R, Kolanos R, DiNovi MJ et al (2017) Dietary exposures for the safety assessment of seven emulsifiers commonly added to foods in the United States and implications for safety. Food Add Cont Part A 34(6):905-917. https://doi.org/10.1080/19440049.2017.1311420

Shaker DS, Ishak RA, Ghoneim A et al (2019) Nanoemulsion: a review on mechanisms for the transdermal delivery of hydrophobic and hydrophilic drugs. Sci Pharm 87(3):17. https://doi.org/10.3390/ scipharm87030017

Singh KK, Vingkar SK (2008) Formulation, antimalarial activity and biodistribution of oral lipid nanoemulsion of primaquine. Int J Pharm 347(1-2):136-143. https://doi.org/10.1016/j.ijpharm.2007.06.035

Smolkova B, El Yamani N, Collins AR et al (2015) Nanoparticles in food. Epigenetic changes induced by nanomaterials and possible impact on health. Food Chem Toxicol 77:64-73. https://doi.org/10.1016/j. fct.2014.12.015

Sonneville-Aubrun O, Simonnet JT, L'alloret F (2004) Nanoemulsions: a new vehicle for skincare products. Adv Colloid Interface Sci 108:145-149. https://doi.org/10.1016/j.cis.2003.10.026

Tan CP, Nakajima M (2005) $\beta$-Carotene nanodispersions: preparation, characterization and stability evaluation. Food Chem 92(4):661671. https://doi.org/10.1016/j.foodchem.2004.08.044

Teo SY, Yew MY, Lee SY et al (2017) In vitro evaluation of novel phenytoin-loaded alkyd nanoemulsions designed for application in topical wound healing. J Pharm Sci 106(1):377-384. https://doi. org/10.1016/j.xphs.2016.06.028

Tiwari S, Tan YM, Amiji M (2006) Preparation and in vitro characterization of multifunctional nanoemulsions for simultaneous MR imaging and targeted drug delivery. J Biomed Nanotechnol 2(3-4):217224. https://doi.org/10.1166/jbn.2006.038

van der Ven C, Gruppen H, de Bont DB et al (2001) Emulsion properties of casein and whey protein hydrolysates and the relation with other hydrolysate characteristics. J Agric Food Chem 49(10):5005-5012. https://doi.org/10.1021/jf010144c

Vo TD, Lynch BS, Roberts A (2019) Dietary exposures to common emulsifiers and their impact on the gut microbiota: is there a cause for concern? Compr Rev Food Sci Food Saf 18(1):31-47. https://doi. org/10.1111/1541-4337.12410

Walia N, Dasgupta N, Ranjan S et al (2019) Methods for nanoemulsion and nanoencapsulation of food bioactives. Environ Chem Lett 17(4):1471-1483. https://doi.org/10.1007/s10311-019-00886-w

Wani TA, Masoodi FA, Jafari SM et al (2018) Safety of nanoemulsions and their regulatory status. In: Nanoemulsions. Academic Press, pp 613-628. https://www.sciencedirect.com/science/book/97801 28118382. Accessed 2 Dec 2020

Wu SH, Hung Y, Mou CY (2013) Compartmentalized hollow silica nanospheres templated from nanoemulsions. Chem Mater 25(3):352364. https://doi.org/10.1016/B978-0-12-811838-2.00019-9

Wulff-Pérez M, Torcello-Gómez A, Gálvez-Ruíz MJ et al (2009) Stability of emulsions for parenteral feeding: Preparation and characterization of $\mathrm{o} / \mathrm{w}$ nanoemulsions with natural oils and Pluronic f68 as surfactant. Food Hydrocoll 23(4):1096-1102. https://doi.org/10. 1016/j.foodhyd.2008.09.017

Yen CC, Chen YC, Wu MT et al (2018) Nanoemulsion as a strategy for improving the oral bioavailability and anti-inflammatory activity of andrographolide. Int J Nanomed 13:669. https://doi.org/10.2147/ IJN.S154824

Yu L, Li C, Xu J et al (2012) Highly stable concentrated nanoemulsions by the phase inversion composition method at elevated temperature. Langmuir 28(41):14547-14552. https://doi.org/10.1021/la302995a

Yuan Y, Gao Y, Zhao J et al (2008) Characterization and stability evaluation of $\beta$-carotene nanoemulsions prepared by high pressure homogenization under various emulsifying conditions. Food Res Int 41(1):61-68. https://doi.org/10.1016/j.foodres.2007.09.006

Yukuyama MN, Ghisleni DDM, Pinto TDJA et al (2016) Nanoemulsion: process selection and application in cosmetics-a review. Int J Cosmet Sci 38(1):13-24. https://doi.org/10.1111/ics.12260

Zhang L, Zhang F, Fan Z et al (2019) DHA and EPA nanoemulsions prepared by the low-energy emulsification method: process factors influencing droplet size and physicochemical stability. Food Res Int 121:359-366. https://doi.org/10.1016/j.foodres.2019.03.059

Zhao C, Ashaolu TJ (2020) Bioactivity and safety of whey peptides. LWT 109935. https://doi.org/10.1016/j.lwt.2020.109935

Zhao L, Seth A, Wibowo N et al (2014) Nanoparticle vaccines. Vaccine 32(3):327-337. https://doi.org/10.1016/j.vaccine.2013.11.069

Ziani K, Chang Y, McLandsborough L et al (2011) Influence of surfactant charge on antimicrobial efficacy of surfactant-stabilized thyme oil nanoemulsions. J Agric Food Chem 59(11):6247-6255. https://doi. org/10.1021/jf200450m

Publisher's Note Springer Nature remains neutral with regard to jurisdictional claims in published maps and institutional affiliations. 